\title{
UČINAK FIZIKALNE TERAPIJE NA FUNKCIONALNI OPORAVAK I KVALITETU ŽIVOTA KOD BOLESNIKA S UGRADENOM ENDOPROTEZOM KOLJENA
}

\author{
Sanja Brkić ${ }^{1}$ Lejla Obradović-Salčin ${ }^{1,2}$, Vesna Miljanović Damjanović ${ }^{1.2}$, \\ Mirela Sušac ${ }^{3}$, Ivana Alagić ${ }^{4}$ \\ ${ }^{1}$ Fakultet zdravstvenih studija, Sveučilište u Mostaru, Bosna i Hercegovina
}

${ }^{2}$ Klinika za fizikalnu medicinu i rehabilitaciju Sveučilišne kliničke bolnice Mostar, Bosna i Hercegovina

${ }^{3}$ Sveučilišna klinička bolnica Mostar, Bosna i Hercegovina

${ }^{4}$ Berlin-Chemie AG, Sarajevo Bosna i Hercegovina

Rad je primljen 10.5.2017. Rad je recenziran 13.5.2017. Rad je prihvaćen 15.5.2017.

\section{SAŽETAK}

UVOD: Ugradnja totalnih endoproteza koljena (TPK) u porastu je posljednje tri decenije, što je posljedica porasta broja stanovnika starije životne dobi s većom potrebom za liječenjem bolnih, degenerativno izmijenjenih zglobova.

CILJ: Ispitati učinak fizikalne terapije na funkcionalni oporavak i kvalitetu života (KŽ) u bolesnika s ugrađenom endoprotezom koljena.

ISPITANICI I POSTUPCI: Istraživanje je provedeno u Klinici za fizikalnu medicinu i rehabilitaciju i Klinici za ortopediju Sveučilišne kliničke bolnice Mostar. Istraživanje je obuhvatilo bolesnike nakon ugradnje TPK tijekom provedbe postoperativnog rehabilitacijskog tretmana. Za procijenu KŽ rabio se EQ-5D-5L upitnik, za procijenu boli vizualno-analogna ljestvica boli (VAS), a za mjerenje opsega pokreta goniometar. Bolesnici su testirani u dva navrata, prije i nakon provedenog rehabilitacijskog tretmana.

REZULTATI: Ispitivanje je obuhvatilo 40 ispitanika, od kojih je $72,5 \%$ bilo ženskog spola ( $\mathrm{p}=0,004)$. Prosječna životna dob ispitanika bila je $67,9 \pm 5,1$ godina. Pokazalo se statistički značajno povećanje fleksije $(\mathrm{p}<0,05)$ i ekstenzije $(\mathrm{p}<0,05)$ zgloba koljena nakon provedenog tretmana. Ispitanici su značajno bolje ocijenili pokretljivost $(\mathrm{p}<0,05)$, uobičajene aktivnosti $(\mathrm{p}<0,05)$, bol i nelagodu $(\mathrm{p}=0,003)$, tjeskobu i potištenost $(\mathrm{p}=0,029)$, te su statistički značajno većom ocjenom procijenili svoje zdravlje $(\mathrm{p}<0,05)$. Pokazala se statistički značajna negativna korelacija između životne dobi i KŽ ispitanika $(\mathrm{p}<0,05)$. ZAKLJUČAK: Provedba ranog rehabilitacijskog programa u bolesnika s ugrađenom TPK dovodi do značajnog povećanja većeg opsega pokreta zgloba koljena, manjeg osjećaja boli i veće funkcionalne sposobnosti i adaptacije te KŽ.

Ključne riječi: koljeno, totalna endoproteza, postoperativni program, rehabilitacija.

Osoba za razmjenu informacija:

Sanja Brkić, magistar fizioterapije

e-mail: sanjabrkic112@gmail.com

\section{UVOD}

Ugradnja totalnih endoproteza koljena (TPK) u porastu je posljednje tri decenije, što je posljedica porasta broja stanovnika starije životne dobi i njihove veće potrebe za liječenjem bolnih, degenerativno izmijenjenih zglobova (1). Ugradnja umjetnih zglobova je jedno od najuspješnijih dostignuća medicine 20. stoljeća. Radi se o kirurškom zahvatu u kojem se potpuno ili djelomično zamjenjuju zglobna tijela oštećenog zgloba (2). Kod TPK zamjenjuje se čitav zglob. Najpopularnije su bikondilarne cementne ili bescementne proteze. Femoralni dio proteze građen je metala (najčešće od legure kobalta i kroma) koji se ugrađuje na kondile. Tibijalni dio endoproteze također je građen od metala (obično je od titanija ili legure kobalt-kroma), dok je umetak građen od polietilenske plastike. Iverni dio nadograđuje se polietilenom, 
nekad polietilenom na metalnoj bazi. Kod ugradnje TPK kolateralni ligamenti ostaju očuvani, dok se stražnja ukrižena sveza može i ne mora očuvati (3).

Najčešća indikacija za operaciju je degenerativna promjena zgloba (4). Ostale indikacije su: ispravak deformiteta, reumatoidni artritis, psorijatični artritis, tumor, trauma. Kontraindikacije za operaciju su: periferna vaskularna bolest, osteomijelitis, lokalna infekcija ili ozljeda kože, uznapredovala osteoporoza i dr. (5). Totalna artroplastika koljena dokazano je efikasna, jer omogućava bolesnicima ponovno uspostavljanje izgubljene funkcije zgloba i poboljšanje kvalitete života (KŽ). Ugradnjom TPK uklanja se bol, poboljšava funkcija, omogućuje se bolesniku samostalan život što pridonosi poboljšanju KŽ (6).

Dok su endoproteze zgloba kuka dobro tehnički riješene te se primjenjuju s velikim uspjehom, TPK još nisu dostigle tu razinu zbog zahtjevne biomehanike zgloba koljena. Međutim, liječenje bolesnih zglobova ne završava se operativnim zahvatom. Krajnji cilj je osigurati pokret bez bola i time poboljšati pacijentovu KŽ, koju Svjetska Zdravstvena Organizacija (SZO) definira kao multidimenzionalni model koji uključuje fizičko, emocionalno i socijalno dobro stanje (7). Dobri funkcionalni rezultati nakon TPK ovise od dobro uvježbanog i iskusnog ortopedskog tima, ali i od stručnog fizijatrijsko rehabilitacijskog tima, pri čemu je neophodna obostrana horizontalna komunikacija svih članova tima (8). Zadatci uspješne rehabilitacije nakon implantacije TPK usmjereni su prema bezbolnim pokretima operiranog zgloba, poboljšanju opsega pokreta, uspostavljanju korektne sheme hoda, pri čemu hod treba biti ekonomičan i estetski zadovoljavajući, kao i na postizanju neovisnosti u aktivnostima svakodnevnog života $(9,10)$.

Već prvi dan nakon operacije bolesnici počinju hodati, uz pomoć dvije štake i uz stručni nadzor fizioterapeuta. Uz to, izvode vježbe za jačanje muskulature te uče dozvoljene kretnje u ranom postoperacijskom razdoblju. Nakon odstranjenja konaca bolesnici se otpuštaju iz bolnice i nastavljaju rehabilitaciju.

Mjesec dana nakon operacije većina pacijenata započinje hod uz pomoć jedne štake (u ruci suprotnoj od operirane noge). Šest mjeseci nakon operacije pacijentu je zabranjeno podizanje teških tereta i izvođenje rotirajućih pokreta u operiranom zglobu. Rana rehabilitacija većini pacijenata omogućuje brz oporavak i povratak svakodnevnim aktivnostima, kroz četiri do osam tjedana. Šest tjedana nakon operacije pacijent dolazi na kontrolni pregled. Sljedeći pregled je za tri, zatim šest mjeseci, nakon čega slijede kontrolni pregledi jednom godišnje (11).

Vježbe i funkcionalni trening treba započeti nulti ili prvi postoperativni dan s frekvencijom od dva puta dnevno do otpuštanja bolesnika. Pacijent bi trebao što češće provoditi naučene vježbe tokom boravka u bolnici. Glavni ciljevi postoperativne rehabilitacije su prevencija vaskularnih i pulmonalnih komplikacija. Nakon uspostavljanja kontrole nad operiranom nogom koriste se aktivne vježbe kao što su aktivna fleksija i ekstenzija u koljenu u sjedećem položaju. U završnoj fazi, nakon otprilike 8 - 10 tjedana prelazi se na vježbe za povećanje mišićne jakosti i izdržljivosti, stabilnosti i ravnoteže i postizanje normalnog opsega pokreta za normalno funkcioniranje. Za ponovno postizanje optimalne jakosti i izdržljivosti mišića koriste se vježbe dozvoljenog opsega pokreta s malim otporom gdje se $s$ vremenom povećava samo broj ponavljanja (12).

\section{CILJ ISTRAŽIVANJA}

Ispitati učinak fizikalne terapije na funkcionalni oporavak i KŽ u bolesnika s ugrađenom endoprotezom koljena. Sporedni cilj je bio utvrditi postoji li korelacija KZ̆ bolesnika sa spolom i dobi.

\section{ISPITANICI I POSTUPCI}

Istraživanje je provedeno u Klinici za fizikalnu medicinu i rehabilitaciju i Klinici za ortopediju Sveučilišne kliničke bolnice Mostar. Istraživanje je obuhvatilo 40 ispitanika, oba spola, starosti od 45 do 85 godina. Kriterij uključivanja u istraživanje bili su bolesnici s degenerativnim promjenama na zglobu koljena kojima je ugrađena TPK. Kriteriji isključenja u istraživanju bili su bolesnici s infekcijskim artritisom, s neinfektivnim upalnim reumatizmom, $s$ malignim tumorima, osobe s metaboličkim bolestima kostiju i zglobova, osobe s infektivnim bolestima i insuficijentnim srčanožilnim i respiratornim sustavom. 
Kako bi se procijenila KŽ bolesnika rabio se EQ5D-5L upitnik o zdravlju verzija za Hrvatsku (EuroQol - EQ-5D-5L) koji se sastoji od pet domena, od kojih svaka ima pet čestica:

1. Prva domena se sastoji od pet pitanja kojima se procjenjuju problemi u kretanju.

2. Druga domena se sastoji od pet pitanja kojima se ispituje problem s osobnom higijenom i odijevanjem.

3. Treća domena se sastoji od pet pitanja kojima se utvrđuje razina uobičajenih aktivnosti, a odnose se na posao, obavljanje kućnih poslova, aktivnosti u obitelji ili u slobodno vrijeme.

4. Četvrta domena se sastoji od pet pitanja kojima se utvrđuje razina boli ili nelagode $u$ odnosu na operirani zglob.

5. Peta domena se sastoji od pet pitanja kojima se utvrđuje razina tjeskobe i potištenosti. Na kraju upitnika nalazi se ocjena zdravlja bolesnika danas, kojim se utvrđuje njihovo zdravlje danas kao dobro ili loše.

Prvo pitanje u domeni označava najbolji rezultat dok posljednje označava najgori (12).

$\mathrm{Za}$ procjenu osjećaja boli rabljena je vizualno-analogna ljestvica boli (VAS). VAS se standardno upotrebljava za subjektivnu procjenu boli kod svih pacijenata s kroničnim bolnim stanjima lokomotornog sustava. Od ispitanika se traži da na 10 centimetara dugoj crti označi mjesto koje odgovara jačini njegove boli, nakon čega se s druge strane milimetarske ljestvice očita VAS zbroj. Pritom 0 označava da nema boli, a 10 najjaču bol. Ako je VAS zbroj 0 - 3, jačina boli ne zahtijeva analgetsku terapiju (13). U naše israživanje su uključeni bolesnici koji su svoju bol ocijenili s ocijenom od 5,6 do 6,6.

Za mjerenje opsega pokreta korišten je goniome$\operatorname{tar}(14)$.

Bolesnici su testirani u dva navrata, prije i nakon provedenog rehabilitacijskog tretmana. Prije ispunjavanja mijernih testova israživač je svakom pacijentu objasnio cilj istraživanja, potom da je istraživanje anonimno kao i da neće imati negativnih posljedica na zdravlje pacijenta nakon čega su ispitanici potpisali informirani pristanak.

\section{Statistička obradba podataka}

Distribucija vjerojatnosti kvantitativnih varijabli testirana je na normalnost Smirnov-Kolmogorovljevim testom. Podatci čija raspodjela varijabli nije odstupala od normalne prezentirani su kao aritmetičke sredine (M) i standardne devijacije (SD), te je pri utvrđivanju statističkih razlika rabljen t-test za nezavisne uzorke. Za prikaz srednje vrijednosti i mjere raspršenja kod kontinuiranih varijabli čija je raspodjela značajno odstupala od normalne korišteni su medijan (M) i interkvartilni raspon (Ir), a za utvrđivanje razlika među skupinama koristio se Kruskal-Wallis test. Za analizu nominalnih varijabli korišten je $\chi^{2}$ test. Povezanost $K \check{Z}$ i funkcionalnog oporavka sa spolom i životnom dobi ispitanika procijenjena je Spearmanovim koeficijentom korelacije ranga. Mogućnost pogreške prihvatila se pri $\alpha<0,05$ te su razlike između skupina bile prihvaćene kao statistički značajne za $p<0,05$. P vrijednosti koje se nisu mogle iskazati do najviše tri decimalna mjesta, prikazane su kao $\mathrm{p}<0,001$. Za statističku analizu dobivenih podataka rabljen je programski sustav SPSS for Windows (inačica 13.0, SPSS Inc, Chicago, Illinois, SAD) i Microsoft Excell (inačica Office 2007, Microsoft Corporation, Redmond, WA, SAD).

\section{REZULTATI}

\section{Sociodemografske značajke ispitanika}

Od ukupno 40 ispitanika koje je obuhvatilo istraživanje, njih 29 (72,5 \%) bile su žene, dok je muškaraca bilo $11(27,5 \%)$, što se pokazalo statistički značajno $\left(\chi^{2}\right.$ test $=8,120$; d.f. $\left.1 ; \mathrm{p}=0,004\right)($ Slika 1$)$.

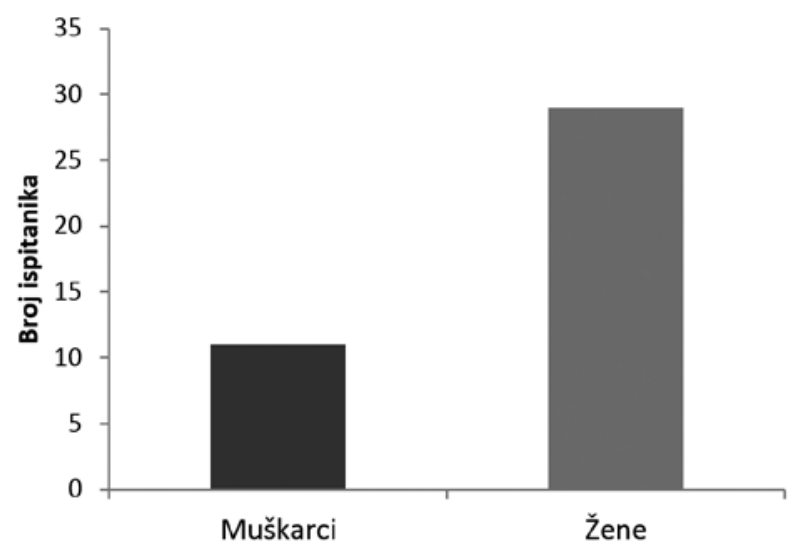

Slika 1. Spolna raspodjela bolesnika s ugrađenom TPK 
Prosječna životna dob ispitanika bila je $67,9 \pm 5,1$ godina. Prosječna dob muškaraca bila je 72,5 $\pm 5,3$ godina, dok je ista u žena iznosila $66,3 \pm 3,7$ što se pokazalo statistički značajno $(\mathrm{t}=3,912$; d.f. $38 ; \mathrm{p}<0,05)$ (Slika 2).

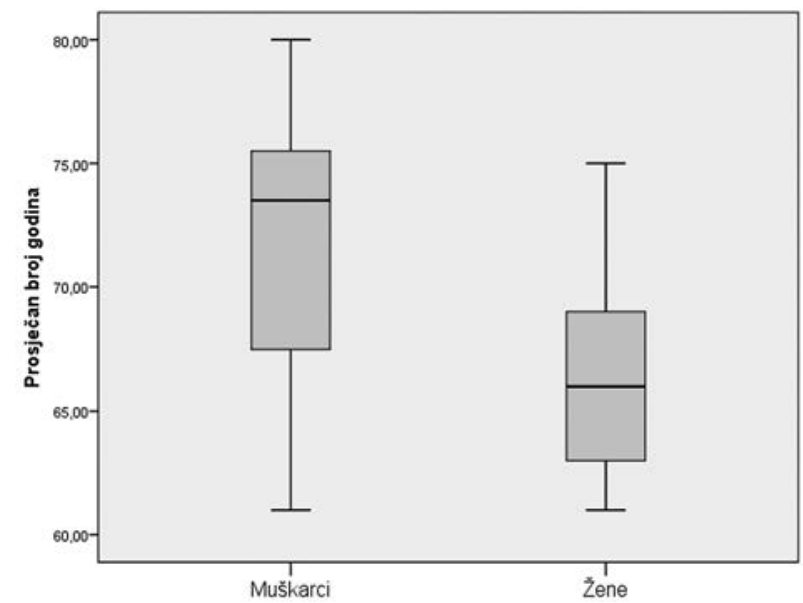

Slika 2. Usporedba prosječne životne dobi prema spolu ispitanika

\section{Usporedba rezultata ocjene boli mjerene vizualno analognom ljestvicom}

Razlike u procjenama jačine boli testirane su t-testom. Obradom rezultata mjerenja prije i nakon završetka rehabilitacijskog programa utvrđena je značajna razlika. Ispitanici su svoj osjećaj boli prije započinjanja tretmana ocijenili prosječnom ocjenom $5,6 \pm 1,1$, dok su po završetku rehabilitacijskog programa svoju bol ocijenili ocjenom $3,5 \pm 0,7$ što se pokazalo statistički značajno $(t=7,018$, d.f. 38 ; $\mathrm{p}<0,05)$ (Slika 3).

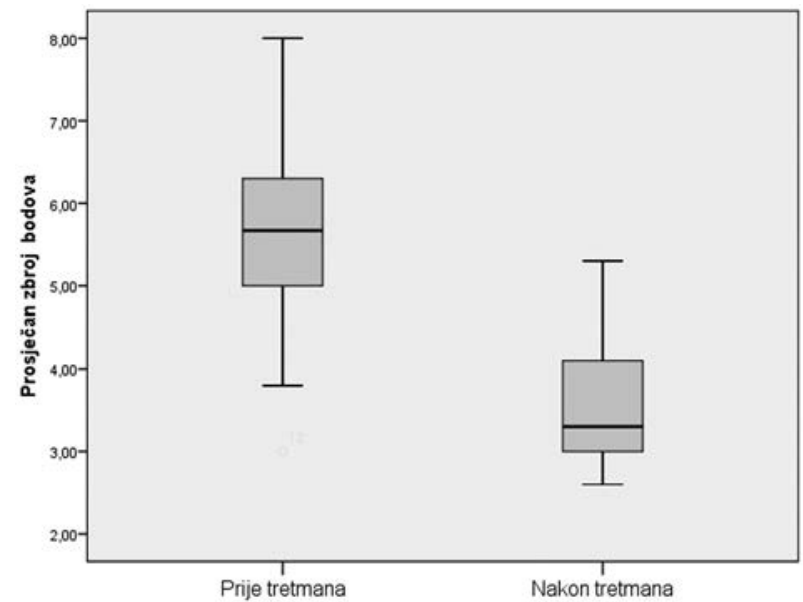

Slika 3. Rezultati mjerenja ocjene boli pomoću VAS ljestvice prije i nakon terapijskih procedura

\section{Usporedba rezultata opsega pokreta zgloba koljena}

Razlike u procjenama opsega pokreta zgloba koljena izražene u stupnjevima, učinjene su t-testom. Obradom rezultata mjerenja prije i nakon završetka rehabilitacijskog programa utvrđena je značajna razlika. Prosječna vrijednost fleksije zgloba koljena $\mathrm{u}$ ispitanika prije započinjanja tretmana iznosila je 85,1 stupnjeva, dok je ista nakon završetka tretmana iznosila 104,0 stupnjeva što se pokazalo statistički značajno ( $\mathrm{t}=-20,044 ;$ d.f. 38; $\mathrm{p}<0,05)($ Slika 4$)$.

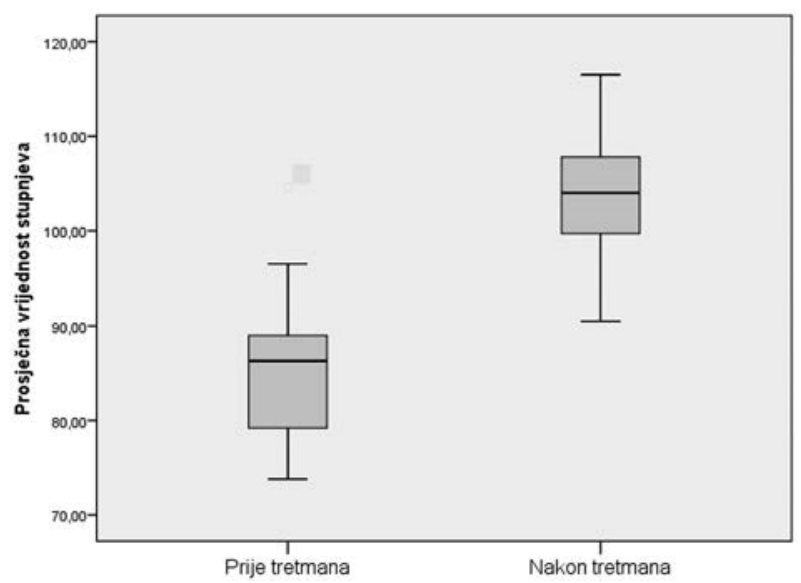

Slika 4. Rezultati mjerenja fleksije zgloba koljena prije i nakon terapijskih procedura

Prosječna vrijednost zaostajanja ekstenzije koljenog zgloba $\mathrm{u}$ ispitanika prije započinjanja tretmana iznosila je 10,9 stupnjeva, dok je ista nakon završetka tretmana iznosila 5,8 stupnjeva što se pokazalo statistički značajno $(\mathrm{t}=12,502 ;$ d.f. $38 ; \mathrm{p}<0,05)$ (Slika $5)$.

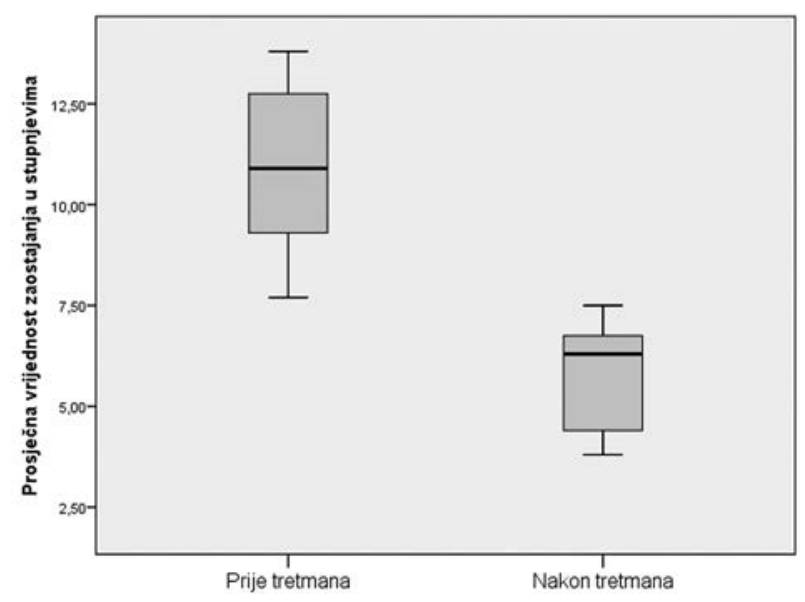

Slika 5. Rezultati mjerenja ekstenzije zgloba koljena prije i nakon terapijskih procedura 


\section{Kvaliteta života ispitanika izmjerena upitnikom EQ-5D-5L}

Razlike u procjenama KŽ izmjerene upitnikom EQ5D-5L testirane su s Wilcoxon-ovim testom. Ispitanici su nakon završenog tretmana statistički značajno bolje ocijenili pokretljivost $(\mathrm{p}<0,05)$, uobičajene aktivnosti $(\mathrm{p}=0,037)$, bol i nelagodu $(\mathrm{p}=0,003)$ i tjeskobu i potištenost $(\mathrm{p}=0,034)$, te su statistički značajno većom ocjenom procijenili svoje zdravlje $(\mathrm{p}<0,05)$ (Tablica 1$)$.

Tablica 1. Samoprocjena kvalitete života u ispitanika prije i nakon rehabilitacijskog tretmana izmjerena upitnikom EQ-5D-5L

\begin{tabular}{|c|c|c|c|c|c|c|}
\hline \multirow{2}{*}{ Domena } & \multicolumn{2}{|c|}{ Prije tretmana } & \multicolumn{2}{|c|}{ Nakon tretmana } & \multirow{2}{*}{ Z } & \multirow{2}{*}{$p$} \\
\hline & $M^{*}$ & $\mid r^{* *}$ & M & Ir & & \\
\hline Pokretljivost & 3 & 3-4 & 2 & $2-3$ & 3,182 & $<0,05$ \\
\hline Skrb o sebi & 3 & $2-3$ & 2 & $1-3$ & 0,863 & 0,358 \\
\hline Uobičajene aktivnosti & 3 & $2-3$ & 2 & $1-3$ & 2,457 & 0,037 \\
\hline Bol inelagoda & 3 & $1-2$ & 2 & $1-3$ & 2,878 & 0,004 \\
\hline Tjeskoba i potištenost & 3 & $1-3$ & 2 & $2-3$ & 2,453 & 0,034 \\
\hline Samoprocjena zdravlja & 68 & $59-70$ & 80 & $76-88$ & 3,060 & $<0,05$ \\
\hline
\end{tabular}

\section{Korelacija kvalitete života izmjerene upitnikom EQ-5D-5L sa spolom i životnom dobi ispitanika}

U tablici 2. prikazani su Spearmanovi koeficijenti korelacije rangova između KŽ izmjerene upitnikom EQ-5D-5L i životne dobi i spola ispitanika. Pokazala se statistički značajna negativna korelacija između dobi i KŽ ispitanika ( $<<0,05)$. Spolna pripadnost ispitanika nije pokazala statistički značajnu korelaciju s izmjerenom KŽ.

Tablica 2. Korelacija kvalitete života sa spolom $i \check{z} i$ votnom dobi ispitanika

\begin{tabular}{lcc}
\hline & \multicolumn{2}{c}{ Kvaliteta života } \\
\cline { 2 - 3 } & Spearman's rho & $p$ \\
\hline Spol & 0,986 & $<0,05$ \\
\hline Dob & 0,083 & 0,270 \\
\hline
\end{tabular}

\section{RASPRAVA}

U ovoj studiji ispitivana je uloga poslijeoperacijske fizikalne terapije i medicinske rehabilitacije na oporavak i KŽ pacijenata s implantiranom TPK. To je česta, pouzdana kirurška operacija koja se izvodi u kasnijim stadijima degenerativne bolesti koljena, koja ima tendenciju da postane veliki zdravstveni problem s mogućim utjecajem na svakodnevni život.

Barlow i suradnici navode učestaliju ugradnju TPK u žena što je u skladu s rezultatima našeg istraživanja $(1,2,7,15,16)$. Daljom raščlambom ustanovljeno je da su muški bolesnici u statistički značajno većoj životnoj dobi u odnosu na žene. U našem istraživanju prosječna dob za muškarce je 72,5 godina, a za žene 66,3 godina. Parsley u svojoj meta analizi navodi da su žene $s$ ugrađenom TPK u prosjeku četiri godine mlađe od muškaraca (14). Kuder i suradnici u svojoj multicentričnoj studiji navode podatak da su bolesti zglobova tri puta češće $u$ žena u odnosu na muškarce (17). Dosadašnja istraživanja su pokazala slične stope zamjene zgloba koljena ili kuka kod žena (6 \%) i muškaraca $(5 \%)(18,19)$.

Pokazalo se značajno povećanje mogućnosti fleksije $\mathrm{u}$ ispitanika čija je prosječna vrijednost nakon završenog fizijatrijskog tretmana iznosila 104 stupnja. Mogućnost fleksije koljena od 100 stupnjeva dovodi do boljeg funkcioniranja u aktivnostima svakodnevnog života (20). Jedan od najčešćih učinaka patoloških procesa koljena jeste ograničenje pokretljivosti i nastanak fleksijske kontrakture.

Zbog toga se, opseg pokreta smatra važnom mjerom postoperativnog ishoda.

Nedovoljan raspon pokreta postoperativno može otežati pacijentov povratak u normalan način života. Laubenthal i suradnici navode da je za svakodnevne aktivnosti, kao što je hodanje, potrebna fleksija u koljenu od 67 stupnjeva, za hod uz stepenice 83 stupnja, za hod niz stepenice 90 stupnjeva i za ustajanje iz sjedećeg položaja 93 stupnja (21). Smatra se da bolesnici uglavnom dostižu plato oporavka kroz šest mjeseci. Konačnim postignutim opsegom pokretljivosti smatra se opseg pokretljivosti dobiven unutar godine dana od operativnog zahvata (22). 
Druga važna mjera ishoda operacije je bol. Ublaženje boli značajno unaprjeđuje bolesnikovu KŽ i sposobnost za obavljanje funkcionalnih aktivnosti. Kod svih ispitanika utvrđeno je značajno poboljšanje u smislu smanjenja boli, mjereno prema VAS. Na početku rehabilitacijskog tretmana bolesnici su razinu boli prema VAS procijenili s ocjenom $5,6 \pm 1,1$ a nakon provedenog rehabilitacijskog tretmana $3,5 \pm 0,7$. Gotovo svi bolesnici nakon ugradnje TPK izvještavaju o značajnom smanjenju boli tijekom pokretanja koljena, opterećivanja i hoda $(23,24)$.

Jedan od primarnih kliničkih ciljeva ovog istraživanja bilo je ispitati $\mathrm{KŽ} \mathrm{pacijenata} \mathrm{nakon} \mathrm{implanta-}$ cije TPK i medicinske rehabilitacije što je procjenjivano s upitnikom EQ-5D-5L. U našem istraživanju utvrdili smo da postoji razlika u vrijednostima skora na početku i na kraju rehabilitacijskog tretmana. Dobiveni rezultati ukazuju na to da nastavak rane rehabilitacije kod pacijenata s učinjenom TPK ima pozitivan učinak na funkciju, odnosno na $K Z \check{Z}$, što se podudara s rezultatima drugih autora $(25,26)$.

Do sličnih zaključaka došli su i drugi autori. Papakostidou sa suradnicima ističe da je od svih mjerenja najveći napredak primijećen u prva tri postoperativna mjeseca sa manjim promjenama kasnije (15). Otkriće na području ranog funkcionalnog oporavka je u skladu s otkrićima iz drugih studija, koji ukazuju da se nakon početnog perioda funkcionalne ograničenosti pacijentovo stanje popravlja tri mjeseca nakon operacije.

Pokazala se i negativna korelacija između životne dobi bolesnika i ocjene KŽ dobivene upitnikom. Postoji sveza između godina u vrijeme vršenja operacija i ishoda operacija, uz opasku da će mlađi bolesnici imati trend boljeg oporavka, ali će mlađi od 55 godina vjerojatno biti manje zadovoljni operacijom, te se savjetuje oprez prilikom zagovaranja operacije kod ove starosne grupe (24). Ipak, ova korelacija više životne dobi i zadovoljstva KŽ ukazuje na potrebu da se rehabilitacija ovih bolesnika s ugrađenom TPK ne smije usmjeriti samo na poboljšanje funkcionalnosti i smanjivanje bola već je potrebno posvetiti čitav jedan segment skrbi za njihovo mentalno zdravlje i zadovoljstvo KŽ. Vrlo često kod starijih pacijenata postoji i problem socijalne izolacije, loše komunikacije što dovodi do osjećaja bezvoljnosti, a to je također element koji onemogućava adekvatno sudjelovanje u rehabilitaciji od strane pacijenata. Primarni cilj čitavog procesa liječenja i rehabilitacije jeste poboljšanje KŽ ovih pacijenata. Potrebno je osmisliti dodatne specifične suportivne programe $u$ sklopu rehabilitacijskog programa za vulnerabilnije skupine bolesnika u koje svakako spadaju osobe starije životne dobi.

\section{ZAKLJUČAK}

Provedba ranog rehabilitacijskog programa u bolesnika s ugrađenom endoprotezom koljena dovodi do značajnog povećanja većeg opsega pokreta zgloba koljena, manjeg osjećaja boli i veće funkcionalne sposobnosti i adaptacije te KŽ. KZ̆ bolesnika $s$ ugrađenom TPK negativno korelira sa životnom dobi.

\section{LITERATURA}

1. Barlow T, Clark T, Dunbar M, Metcalfe A, Griffin $\mathrm{D}$. The effect of expectation on satisfaction in total knee replacements: a systematic review. Springerplus. 2016; 5:167.

2. Steel N, Melzer D, Gardener E, McWilliams B. Need for and receipt of hip and knee replacement - a national population survey. Rheumatology. 2006; 45:1437-41.

3. Kurtz S, Ong K, Lau E, Mowat F, Halpern M. Projections of primary and revision hip and knee arthroplasty in the United States from 2005 to 2030. J Bone Joint Surg Am. 2007; 89:780-5.

4. Tanzer M, Miller J. The natural history of fl exion contracture in total knee arthroplasty. Clinical Orthopaedics and Related Research. 1999; 248:129-34.

5. Insall J, Kelly M. The total condylar prosthesis. Clin Orthop. 1996; 205:43-58.

6. Healy, Sharma SF, SchwartzB, Iorio R. Current concepts review: Athletic activity after total joint arthrplasty. The journal of bone and joint surgery. 2008; 90:2245-52.

7. Choi YJ, Ra HJ. Patient Satisfaction after Total Knee Arthroplasty. Knee Surg Relat Res. 2016; 28:1-15. 
8. Shan L, Shan B, Suzuki A, Nouh F, Saxena A. Intermediate and long-term quality of life after total knee replacement: a systematic review and meta-analysis. J Bone Joint Surg Am. 2015; 97:156-68

9. Paxton RJ, Melanson EL, Stevens-Lapsley JE, Christiansen CL. Physical activity after total knee arthroplasty: A critical review. World J Orthop. 2015; 6:614-22.

10. Papakostidou I, Dailiana ZH, Papapolychroniou $T$, et al. Factors affecting the quality of life after total knee arthroplasties: a prospective study. BMC Musculoskelet Disord. 2012; 13:116.

11. Kosinac Z. Kineziterapija: Tretmani poremećaja i bolesti organai organskih sustava. Split: Sveučilište u Splitu; 2006.

12. Rabin R, de Charro F. EQ-5D: a measure of health status from the EuroQol Group. Ann Med. 2001; 33:337-43.

13. Boonstra AM, Schiphorst Preuper HR, Reneman MF, Posthumus JB, Stewart RE. Reliability and validity of the visual analogue scale for disability in patients with chronic musculoskeletal pain. Int J Rehabil Res. 2008; 31:165-9.

14. Parsley BS. Influence of Gender on Age of Treatment with TKA and Functional Outcome. Clin Orthop Relat Res. 2010; 468:1759-64.

15. Papakostidou I, Dailiana ZH, Papapolychroniou T. Factors affecting the quality of life after total knee arthroplasties: a prospective study. BMC Musculoskelet Disord. 2012; 13:116-23.

16. Bugała-Szpak J, Kusz D, Dyner-Jama I. Early evaluation of quality of life and clinical parameters after total knee arthroplasty. Ortopedia, traumatologia, rehabilitacija. 2009; 12:41-9.

17. Kuder SA, Peshimam AZ, Agraharam S. Environmental risk factors for rheumatoid arthritis. Rev Environ Health. 2009; 17:307-15.
18. Steel N, Melzer D, Gardener E, McWilliams B. Need for and receipt of hip and knee replacement- a national population survey. Rheumatology. 2006; 45:1437-41.

19. Puolakka PA, Rorarius MG, Roviola M, Puolakka TJ, Nordhausen K, Lindgren L. Persistent pain following knee arthroplasty. Eur J Anaesthesiol. 2010; 27:455-60.

20. Harvey IA, Barry K, Kirby SPJ, Johnson R, Elloy MA. Factors affecting the range of movement of total knee arthroplasty. J Bone Joint Surg Br. 1993; 75: 950-5.

21.Laubenthal KN, Smidt GL, Kettelkamp DB. A quantitative analysis of knee motion during activities of daily living. Phys Ther. 1972; 52:34-43.

22. Minns Lowe CJ, Barker KL, Dewey M, Sackley CM. Effectiveness of physiotherapy exercise after knee arthroplasty for osteoarthritis: systematic review and meta-analysis of randomised controlled trials. BMC Musculoskelet Disord. 2009; 10: 98.

23. Finch E, Walsh M, Thomas SG, Woodhouse LJ. Functional ability perceived by individuals following total knee arthroplasty compared to agematched individuals without knee disability. J Orthop Sports Phys Ther. 1998; 27:255-63.

24. Walsh M, Woodhoude LJ, Thomas SG, Finch E. Physical impairments and functional limitations: a comparison of individuals 1 year after total knee arthroplasty with control subjects. Phys Ther. 1998; 78:248-58.

25. Isaac D, Falode T, Liu P, I'Anson H, Dillow K, Gill P. Accelerated rehabilitation after total knee replacement. Knee. 2005; 12:346-50.

26. Lingard EA, Berven S, Katz JN; Kinemax Outcomes Group. Management and care of patients undergoing total knee arthroplasty: variations across different health care settings. Arthritis Care Res. 2000; 13:129-36. 


\title{
EFFECTS OF PHYSICAL THERAPY ON FUNCTIONAL RECOVERY AND QUALITY OF LIFE IN PATIENTS WITH EMBEDDED KNEE ENDOPROSTHESIS
}

\author{
Sanja Brkic ${ }^{1}$, Lejla Obradovic-Salcin ${ }^{1,2}$, Vesna Miljanovic Damjanovic ${ }^{1.2,}$ Mirela Susac ${ }^{3}$, Ivana Alagic ${ }^{4}$ \\ ${ }^{1}$ Faculty of Health Studies, University of Mostar, 88000 Mostar, Bosnia and Herzegovina \\ ${ }^{2}$ Clinic for Physical Medicine and Rehabilitation of the University Clinical Hospital Mostar, \\ 88000 Mostar, Bosnia and Herzegovina \\ ${ }^{3}$ University Clinical Hospital Mostar, 88000 Mostar, Bosnia and Herzegovina \\ ${ }^{4}$ Berlin-Chemie AG, 71000 Sarajevo, Bosna i Hercegovina
}

\begin{abstract}
INTRODUCTION: The implantation of total knee endoprosthesis (TKE) has been increasing for the last three decades, as a result of an increase in the number of elderly people with a greater need for the treatment of painful, degeneratively modified joints.

OBJECTIVE: Examine the effect of physical therapy on functional recovery and quality of life (QL) in patients with embedded knee endoprosthesis.

PATIENTS AND METHODS: The study was conducted at the Department of Physical Medicine and Rehabilitation and the Department of Orthopedic Surgery, University Clinical Hospital Mostar. The study included patients after TKE was introduced during postoperative rehabilitation treatment. For the assessment of QL, the EQ-5D-5L questionnaire was used, to evaluate the pain, visual-analogue pain scale (VAS) was used, and goniometer was used to measure the circumference of the movement. The patients were tested on two occasions before and after the rehabilitation treatment.

RESULTS: The study included 40 subjects, $72.5 \%$ of whom were female sex $(p=0.004)$. The average age of respondents was $67.9 \pm 5.1$ years. A statistically significant increase in flexion $(\mathrm{p}<0.05)$ and extensions $(\mathrm{p}<0.05)$ of the knee joint was shown after the treatment was performed. Patients significantly better rated mobility $(\mathrm{p}<0.05)$, normal activity $(\mathrm{p}<0.05)$, pain and discomfort $(\mathrm{p}=0.003)$, anxiety and depression $(\mathrm{p}=0.029)$, and they gave statistically significant higher ratings for their health $(\mathrm{p}<0.05)$. Statistically significant negative correlation was found between the age and QL of the respondents $(\mathrm{p}<0.05)$.

CONCLUSION: The implementation of an early rehabilitation program in the patients with the embedded TKE leads to a significant increase in the greater extent of the knee joint movement, lower feeling of pain and greater functional abilities and adaptations, and QL.
\end{abstract}

Key words: knee, total endoprosthesis, postoperative program, rehabilitation.

Correspondence:

Sanja Brkic, Master of Physiotherapy

E-mail: sanjabrkic112@gmail.com 